Article

\title{
Corporate Social Responsibility and Employees' Negative Behaviors under Abusive Supervision: A Multilevel Insight
}

\author{
Faisal Mahmood ${ }^{1, *} \mathbb{0}$, Faisal Qadeer ${ }^{1}$, Zaheer Abbas ${ }^{2}$, Muhammadi $^{3}$, Iqtidar Hussain ${ }^{3}$, \\ Maria Saleem ${ }^{1}$, Akhlaq Hussain ${ }^{4}$ and Jaffar Aman ${ }^{5}$ \\ 1 Lahore Business School, the University of Lahore, Lahore 54000, Pakistan; drfaisalqadeer@gmail.com (F.Q.); \\ mariyasaleem1989@gmail.com (M.S.) \\ 2 School of Management and Economics, Kunming University of Sciences and Technology, Kunming 650000, \\ China; bagoro1214@stu.edu.cn \\ 3 School of International Relations and Public Affairs, Shanghai International Studies University, \\ Shanghai 200000, China; muhammadi@shisu.edu.cn (M.); qambarih@shisu.edu.cn (I.H.) \\ 4 School of Economics and Management, Shanghai University of Sport China, Shanghai 200000, China; \\ akhlaq915@gmail.com \\ 5 Postdoctoral Station of Public Administration and Sociology, Hohai University Nanjing, Nanjing 210000, \\ China; amanjafar5@yahoo.com \\ * Correspondence: faisalch62@gmail.com
}

Received: 26 February 2020; Accepted: 19 March 2020; Published: 26 March 2020

\begin{abstract}
This study attempts to advance the current research debate on corporate social responsibility (CSR) at the micro-level by empirically examining the effect of perceived CSR on employee behaviors such as turnover intention and workplace deviance with the mediation mechanism of organizational identification. The boundary condition of group-level abusive supervision also enhances the novelty of this research. Social identity theory is used for hypotheses development. Multilevel data is collected from 410 middle managers working in thirteen commercial banks in Pakistan by conducting three surveys with temporal breaks. Our results suggest that employees' perceived CSR is statistically and inversely related to their turnover intention and deviant behavior, along with the mediation mechanism of organizational identification. Further, this relationship is weakened with the moderation of abusive supervision. Specifically, our findings indicate that employees' positive CSR perceptions minimize their undesired workplace behaviors through the mediation of organizational identification. But this effect becomes less effective with the contingency of abusive supervision. Our results reveal several means by which organizations can manage their CSR initiatives and human resources, for instance by concentrating on abusive supervision while evaluating their employees' behavior.
\end{abstract}

Keywords: corporate social responsibility; organizational identification; abusive supervision; turnover intention; workplace deviance

\section{Introduction}

Corporate social responsibility (CSR) is seen as an increasingly essential topic of research for scholars in the field of management and has become a mainstream practice for organizations as well. Existing research has investigated the concept of CSR from various viewpoints such as the antecedents and outcomes of CSR. Numerous attempts have been made to investigate the ability of organizational CSR initiatives to positively affect the behaviors of its employees through the lens of social identity theory. These positive impacts include employees' positive perceptions towards their companies' CSR and employees' organizational citizenship behavior [1], job satisfaction [2] and 
organizational identification [3]. In addition, there has been a recommendation to consider employees while developing social sustainability measures [4] and dedication of], as well as increased focus on special issues involving micro-CSR from organization behavior and human resource management journals [5]. However, this debate remains incomplete in various ways. For instance, there is still no defined mechanism to explain the effect of CSR perceptions on employees' behaviors. Moreover, the existing stream of literature on this relationship has largely unnoticed various boundary conditions that can potentially affect this relationship such as individual dissimilarities and managerial traits [6]. Secondly, most of the micro-CSR studies attempt to explain useful positive employer behaviors and studies rarely take this conversation towards the curtailment of negative employee behaviors. Thirdly, the majority of the CSR research is at the firm or individual level. But there is little multilevel evidence [7]. Finally, this research insufficiency is particularly clear in developing countries [8] like Pakistan [9]. This scarcity of research might prevent management from executing and advising on their organizational CSR initiatives [10]. Thus, a prudently established comprehensive mechanism is required to understand one important question: how and under what conditions are CSR perceptions related to negative employee behaviors?

Accordingly, the present research intends to fill these gaps by investigating the effect of employees' CSR perceptions on their undesired workplace behaviors (turnover intention and organizational deviance) through the mediation of organizational identification. Previous studies found a positive effect of organizations' CSR initiatives on their employees' behaviors [11,12] and developed various theoretical frameworks to understand the employees' CSR perceptions and behaviors. Despite this, existing research has not discussed whether employees react negatively to firms' CSR initiatives when a perception of abusive supervision exists and how this affects employees' outcomes.

Drawing on social identity theory, this study argues that organizations' CSR activities lead them to enhance employees' perception of oneness with the organization, as employees consider their organizational membership to be worthwhile and identify themselves with a socially responsible organization. Employees' organizational identification not only builds a persistent association with the organization but their need for self-respect is also satisfied, thereby motivating them to improve their work-related positive behaviors such as reduced turnover intention and workplace deviant behavior. Furthermore, we argue the underlying mechanism of employees' CSR perception with their turnover intention and deviant workplace behavior mediated by organizational identification might be affected by the moderation of group-level abusive supervision. This is because under the condition of group-level abusive supervision, employees are disrespected, teased, discouraged, and treated poorly by their immediate supervisors. Thus, perception of abusive supervision may weak the underlying mechanism of CSR perceptions and employee outcomes mediated by organization identification. This research contributes to micro-CSR, organizational identification, and social identity theory by investigating the mechanism through which perceptions of CSR reduce employees' undesired workplace behaviors. Additionally, the scope of this research is also widened with a focus on the effects of abusive supervision, as very little is known about how employees' perception of immediate supervisors' negative behaviors could influence and worsen the mechanism that usually tends to improve the well-being of organizations by encouraging desired and discouraging undesired workplace behaviors from employees.

\section{Hypotheses Development}

\subsection{Social Identity Theory}

With the seminal work of Albert [12] and Ashforth [13], the concept of organizational identification has become a mainstream topic over the last two decades. Dutton et al. [14] explained that employees assess their self-respect according to the social position or standing of the organization they belong to. In addition, they would strongly identify with the organizations which they perceive to have positive characteristics, values, practices, and structures which are distinct and salient in comparison to other 
organizations. Ashforth [13] (p. 34) defined organizational identification as "the perception of oneness with the organization and considers the achievement and losses of the organization as one's own." The key aspect of social identity theory is the extent to which individuals recognize themselves as being part of a particular social group, leading them to behave similarly to other members of that group [15]. Employees who identify with an organization align the goals of that organization with their own goals $[16,17]$.

\subsection{Mediation of Organizational Identification between CSR and Employee Outcomes}

Aguinis [18] (p. 855) defined CSR is as "context-specific organizational actions and policies that take into account stakeholders' expectations and the triple bottom line of economic, social, and environmental performance". Existing research found positive relationship of employees' CSR perceptions and their workplace behaviors as well as an inverse relationship with undesired behaviors [11]. This research has focused on areas such as employee organizational identification [19], commitment [20], and organizational citizenship behavior [21]. Furthermore, various research has endeavored to establish a mechanism by which CSR perception is related to employee workplace behaviors [22]. For example, mediation of organizational identification has been considered for the link between perceived CSR and employee loyalty, commitment, and job performance [23]. Employees tend to present favorable behaviors at the workplace when they strongly identify with their organization [3]. Firms' CSR initiatives enhance employees' perception of oneness with their organizations, and they tend to identify with their organizations to enhance their self-respect [24,25]. Social identity theory is a leading theoretical perspective to establish the CSR perception and organizational identification relationship, which suggests that employees increase their self-esteem based on the social position of the organization they belong to [19]. CSR tends to increase employees' perception of oneness with their organization, as they consider that the organization is applying procedures and practices that are beneficial for several stakeholders like society, the environment, and employees. As a result, employees' need for self-esteem is satisfied [26].

Turnover intention is "a permanent movement beyond the boundary of an organization" [27] (p. 142). Employees' CSR perceptions enhance organizational identification that can ultimately reduce their intentions to leave that organization. This is because positive CSR perceptions enhance the ability of employees to identify with their organization, which satisfies their need for self-respect and which in turn minimizes their turnover intentions [28,29].

Organizational deviance refers to the "voluntary behavior of organizational members that violates significant organizational norms and, in doing so, threatens the well-being of the organization and its members" [30] (p. 349). Employee deviance consists of both interpersonal deviance (deviance toward other individuals such as behaving rudely or mistreatment of others) and organizational deviance (deviance directed towards the organization, for instance, working slowly, and overlooking tasks) [31]. Deviant behavior of employees towards the organization may consist of misuse, stealing, representing the organization in a negative light, and disrupting organizational resources and these behaviors negatively affect the organization in ways such as wasting time and imposing costs on the organization [32]. This research expects that there is a negative relationship between CSR perceptions and organizational deviance mediated by organizational identification. This is because employees tend to show positive attitudes and behaviors with a higher perception of oneness, while employee organizational deviance is inconsistent with positive feelings of identification and promotes undesirable behavior that undermines the organization [31]. Therefore, we hypothesize that:

Hypothesis 1 (H1). The relationship between CSR perception and turnover intention (H1a) and workplace deviance (H1b) is mediated by organizational identification. 


\subsection{The Boundary Condition of Abusive Supervision}

Tepper [33] (p. 264) explained abusive supervision as "subordinates' perception of the degree to which supervisors involve in the continued exhibition of aggressive verbal and non-verbal behaviors, without physical contact". Abusive supervision can not only involve supervisors' disrespect towards assistants but also publicly teasing and discouraging them [34]. Moreover, Zellars et al. [35] explicated that supervisors' harmful behaviors can include publicly intimidating subordinates, making use of stress tactics, and concealing important information, all of which can result in psychological or emotional oppression [32,36]. Social identity theory explains that stronger identification of employees with their organization diminishes differences by aligning organizational and employee goals, and its spillover effect is to minimize employees' unfavorable workplace behaviors [16,17]. However, researchers have found that employees negatively respond to supervisors' misbehavior by engaging in harmful behaviors towards their organization [37]. The relationship between CSR and organizational identification becomes stronger when employees are not facing abusive supervision. In other words, when employees experience positive behaviors from their supervisor, their feeling of oneness with the organization increases. Therefore, they become much less likely to leave the organization and behave in a deviant manner towards their organization. Accordingly, this research hypothesizes that:

Hypothesis 2 (H2). The indirect effect of CSR perception on turnover intention (H2a) and workplace deviance $(H 2 b)$ with the mediation of organizational identification is influenced by the contingency of abusive supervision, and this effect is stronger when abusive supervision is low than when it is high.

\subsection{Abusive Supervision and Employee Outcomes}

In organizations, employees perform various tasks, and generally, these roles or responsibilities are part of their job description. But sometimes employees engage in positive deviance behaviors, which are not defined in their job description and are not necessarily rewarded. Employees choose to carry out these positive extra-role behaviors to help their organization [32]. Employees can also engage in negative deviance behaviors that adversely affect other employees as well as the organization because they can involve the mishandling of organizational resources or distressing behaviors in the workplace [38]. Deviant behavior toward an organization might consist of absenteeism at work, stealing, and disrupting the resources of an organization. These adverse employee behaviors can incorporate several activities that disrupt an organization in various ways such as wastage of time, taking too much time to complete tasks, or arriving late to work. Thus, all these behaviors yield costs for the organization [32]. Fox et al. [38] argued that workplace violence, misconduct, and non-productive behaviors are the consequences of employee mistreatment perceptions. Existing research has documented unfavorable effects of abusive supervision on employee and organizational outcomes [39] as well as negative responses from employees to supervisor's misbehavior, and suggests that employees tend to engage in disruptive organizational behaviors as a result of these forms of negative treatment [37]. Social exchange theory [40] therefore suggests that employees behave positively when they are treated fairly and negatively respond to misbehavior. Further, drawing on the social exchange theory, it has been suggested that employees present reactive behaviors towards supervisory mistreatment [41]. Thus, existing research has empirically and theoretically suggested that employees respond to abusive supervision by engaging in undesired behaviors in the workplace. Accordingly, this research hypothesizes that:

Hypothesis 3 (H3). Group level abusive supervision positively influences employees' turnover intention (H3a) and workplace deviance $(\mathrm{H} 3 \mathrm{~b})$.

Figure 1 explain the hypothesized model of this research. PCSR represents the perception of CSR and $\mathrm{PCSR}^{*}$ Abusive supervision is the interaction term used to test the moderation of group-level 
abusive supervision. $\mathrm{H} 1 \mathrm{a}$ and $\mathrm{H} 1 \mathrm{~b}$ represents the mediation of organizational identification between PCSR and turnover intention and organizational deviance, respectively. $\mathrm{H} 2 \mathrm{a}$ and $\mathrm{H} 2 \mathrm{~b}$ is the moderation of abusive supervision on the indirect effect of PCSR with turnover intention and organizational deviance with the mediation of organizational identification, respectively. Further, H3a explains the cross-level direct effect of abusive supervision on turnover intention and H3b is the cross-level direct effect of abusive supervision on organizational deviance.

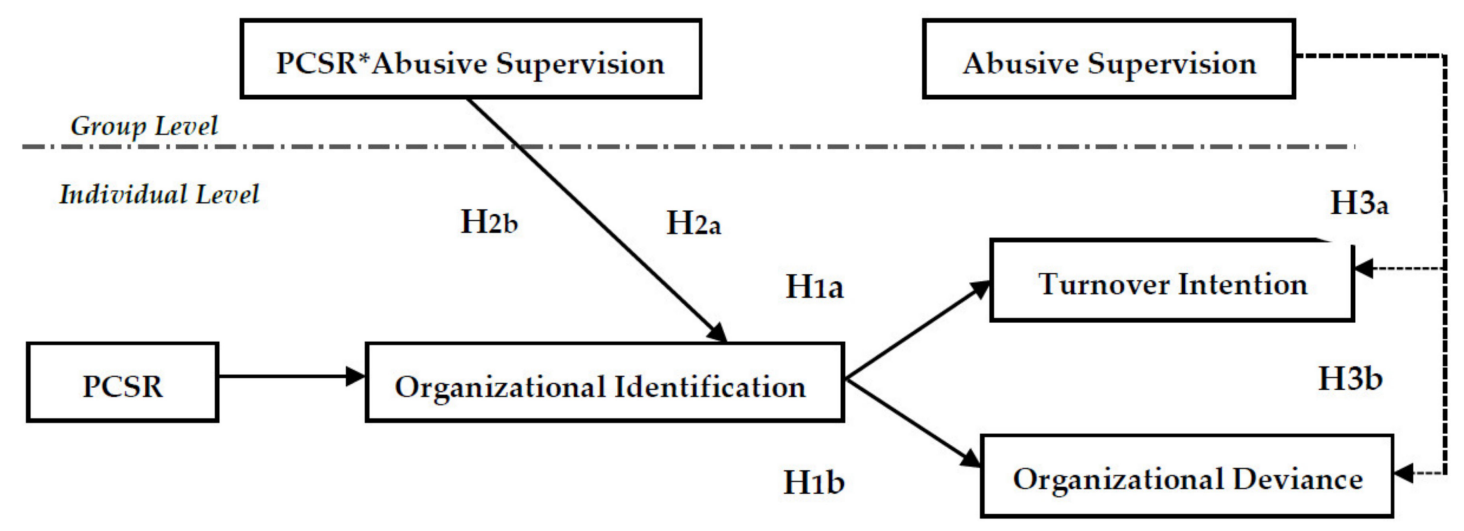

Figure 1. Hypothesized Model.

\section{Materials and Methods}

After considering the purpose of this research, we selected thirteen commercial banks listed on Pakistan's Stock Exchange, which are engaged in CSR activities. These banks specify their CSR objectives on their official websites, which include subsidizing free education for children, providing donations to healthcare institutes, and providing employee benefits. The data for this research were collected from the middle managers working in various branches of all the selected banks. Some recent studies on CSR shed light on the importance of middle managers for data collection in contrast to top managers [42], since middle managers act as a bridge between top managers and operational level employees while participating in the formulation and implementation of organizational strategies. This research employed multi-level and time-lagged data, which is a desirable research design in CSR research $[5,7]$. In survey research, one-time data collection for criterion and predictor variables may cause measurement context effect or method bias [43]. Therefore, to avoid these biases, we collected data in three stages from middle managers using three surveys that were carried out about three weeks apart. The data collection occurred over nine weeks, starting in December 2018 and ending in January 2019.

In the first round, 550 self-administrated questionnaires were distributed among middle managers working in 97 branches to rate their perceptions of CSR and turnover intention, and 487 (88\%) complete and usable questionnaires were received. To overcome respondent concerns [43], all the respondents were guaranteed their anonymity and privacy maintenance. We also assured them that this survey would have no effect on their performance or rewards, and that their responses would be only utilized for research purposes. Further, each respondent provided a four-digit code of their own choice that was used in the follow-up surveys to maintain their anonymity. In the second survey, 487 self-administrative questionnaires were distributed among the middle managers who had completed the first survey to rate their organizational identification and their supervisor's abusive supervision, and we received 453 (93\%) usable questionnaires during this round. In the final round, the third survey was conducted, and the 453 middle managers who had responded during the first and second rounds were again requested to rate their organizational deviance. For this round, $423(94 \%)$ usable questionnaires were obtained. Thus, after the final round, we obtained 423 complete sets of three surveys. Our overall response rate was $76 \%$. After screening data for missing values, outliers, incomplete responses, 
and vague responses, we determined that 410 questionnaire were complete in all areas and suitable for further analysis, which provided a final response rate of $74 \%$.

\subsection{Measures}

This research incorporated well-established scales. Perceived CSR was measured by using a 29 items five-point Likert scale from 1 (Strongly Disagree) to 5 (Strongly Agree) developed by Maignan and Ferrell [44]. The sample items are: "My organization supports employees who acquire additional education," "My organization gives adequate contributions to charities." The Cronbach Alpha value for this scale is 0.93 , which shows high reliability of the scale. Organizational identification was measured by using Mael and Ashforth's [45] 6 items five-point Likert scale ranging from 1 (Strongly Disagree) to 5 (Strongly Agree). The sample items include: "When someone criticizes my organization, it feels like a personal insult," "When someone praises my organization, it feels like a personal compliment." The Cronbach Alpha value for this scale is 0.81 . The turnover intention was measured by making use of Wayne et al.'s [46] 5 items on a five-point Likert scale [ $1=$ strongly disagree; $5=$ strongly agree]. The reliability of this scale measured by Cronbach Alpha is 0.71 . Organizational deviance was measured through Bennett and Robinson's [30] 12 items six-point Likert scale $[1=$ Never; $6=$ Always]. The sample items are, "I spent too much time fantasizing or daydreaming instead of working" and "I intentionally work slower than I can work." The coefficient alphas are 0.88. In our research, organizational deviance was self-reported. Notably, the respondents' immediate supervisors or colleagues might have unreliable information on such organizational deviance behaviors because they are performed secretly most of the time [47]. However, it has also suggested by existing research that organizational deviance can be measured through self-reports if the participants remain anonymous [30]. Abusive supervision was measured by using Tepper's [48] 15 items five-point Likert scale [ $1=$ Never, $5=$ Very often]. The sample items are: "My boss ridicules me," "My supervisor tells me that my thoughts or feelings are stupid." The Cronbach Alpha value for this scale is 0.82 . In Appendix A Table A1 explains all the scales used in this research.

\subsection{Control Variables}

Existing research suggested that respondents' age, gender, education, and organization tenure can influence the association of other variables [11,49], and thus these variables were incorporated as control variables for this research. Respondents' age was measured as a categorical variable, gender was measured on a dichotomous scale with 1 for a male and 0 for a female, while education and organization tenure were measured in years.

\subsection{Analytical Strategy}

Preliminary analysis was conducted in SPSS to test missing values, incomplete responses, outliers, descriptive analysis, and inferential statistics. Confirmatory factor analysis was done by using MPlus [50] to test the constructs' validity of individual-level variables comprising perceived CSR, organizational identification, turnover intention, and organizational deviance and group-level variables such as abusive supervision. MPlus is a statistical modeling program that provides new insights for data analysis, as well as various choices of models and estimators that can be used to analyze data. For instance, cross-sectional, longitudinal, single, and multi-level data all be tested in MPlus. We chose MPlus for our research because we were interested in testing multi-level data. We have adopted five general indexes $\chi 2 / \mathrm{d} f$, root mean square error of approximation (RMSEA), standardized root mean square residual (SRMR), tucker-lewis index (TLI), and comparative fit index (CFI) to estimate the model fit. We chose acceptable cut off values for these fit indices $(<2.00$ for $\chi 2 / \mathrm{d} f,<0.08$ for SRMR and RMSEA, $>0.90$ for CFI and TLI) that are frequently reported and suggested in previous research [51]. Drawing on Chan's [52] typology of direct consensus model, we considered group-level abusive supervision as the aggregation of abusive supervision reported by the group members. In this aggregation, we used abusive supervision measured at the individual-level, not at the group 
level. It was possible to operationalize the mean score of within-group abusive supervision as the group supervision because satisfactory within-group consensus at the individual-level can justify the aggregation of individual-level scores at the group-level $[52,53]$. To establish this consensus, we calculated intraclass correlations (ICC1, ICC2), and rwg ( $j$ ) for abusive supervision by following the methods outlined by Muthén [54] and Preacher et al. [55]. We found that the ICC1 and ICC2 values for abusive supervision were 0.26 and 0.41 , respectively, and median Rwg (j) values were 0.74 . These values are within acceptable limits [56,57] which supported our group-level aggregation, and are also similar to existing multi-level research results $[53,58]$.

\section{Data Analysis and Results}

\subsection{Descriptive Analysis}

Table 1 presents the respondent characteristics. Of the 410 participants, $65.4 \%$ were males; regarding the age of respondents, about $16.8 \%$ ranged from 20 to 25 years old, $49.3 \%$ were in the age bracket of 26 to 35 years old, and $33.9 \%$ were more than 35 years old. In terms of their organizational tenure, $38.3 \%$ of respondents had a 1 to 3 years tenure, while $34.9 \%$ had an organizational tenure of 4 to 5 years. Additionally, $11.5 \%$ and $15.4 \%$ had tenures of 6 to 10 years and more than 10 years, respectively. As far as educational background is concerned, $10.7 \%$ of respondents' have earned a bachelor's degree, and $89.3 \%$ had a master's degree or a higher level of education. Overall, the respondents hold a higher level of education that possibly helped the respondents to better understand the survey questions.

Table 1. Respondent Characteristics.

\begin{tabular}{cccccccc}
\hline & Profile & Frequency & Percentage & & Profile & Frequency & Percentage \\
\hline \multirow{5}{*}{ Gender } & Male & 269 & 65.6 & & $20-25$ & 69 & 16.8 \\
& Female & 141 & 34.4 & Age & $26-35$ & 202 & 49.3 \\
& Total & 410 & 100.0 & & Above 35 & 139 & 33.9 \\
& $1-3$ & 157 & 38.3 & & Graduation & 44 & 10.7 \\
Tenure & $4-5$ & 143 & 34.9 & \multirow{2}{*}{ Edu } & Master & 198 & 48.3 \\
& $6-10$ & 47 & 11.5 & & Above Master & 168 & 41.0 \\
& Above 10 & 63 & 15.4 & & Total & 157 & 100.0 \\
\hline
\end{tabular}

Notes: Self-calculations on SPPS. $\mathrm{N}=410, \mathrm{Edu}=$ Education.

The results reported in Table 2 indicate no severe issue of reliability and validity. Hair [51] suggested that the value of average variance extracted must be greater than 0.50 to establish convergent validity and the value of maximum variance shared should be less than the average variance extracted to confirm discriminant validity, while the value of composite reliability must be greater than 0.70 to ensure there is reliability. The Cronbach Alpha values for all the constructs were more than 0.70 . Discriminant validity of the constructs was also measured through average variance extracted (AVE) and Maximum variance shared (MSV) values. Our values were within an acceptable range, as all the values have an AVE of more than 0.50 and the values of MSV are less than AVE, which shows no issue of validity. Harman's one-factor test was also performed to test for common method biases due to self-reported surveys, and its value for all the variables was less than 0.50 , which implies no such issue for this research. 
Table 2. Scales Reliability and Validity.

\begin{tabular}{cccccc}
\hline Variables & Items & Cronbach Alpha & AVE & MSV & CR \\
\hline Level 1 (Individual) & & & & & \\
Perceived CSR & 29 & 0.93 & 0.52 & 0.31 & 0.89 \\
Organizational Identification & 6 & 0.81 & 0.55 & 0.41 & 0.80 \\
Turnover Intention & 5 & 0.71 & 0.61 & 0.08 & 0.77 \\
Organizational Deviance & 12 & 0.88 & 0.63 & 0.13 & 0.81 \\
\hline Level 2 (Group) & & & & & \\
Abusive supervision & 15 & 0.82 & 0.57 & 0.47 & 0.72 \\
\hline
\end{tabular}

Notes: AVE = Average variance extracted, MSV = Maximum shared variance, and CR = Composite reliability.

Descriptive statistics and bivariate correlation of the variables are shown in Table 3. The mean values, standard deviation (SD), Skewness, and Kurtosis are within an acceptable range i.e., +1.5 , and above -1.5 [59]. For instance, perceived CSR has a high mean value of 3.79 because the sample organizations are renowned for CSR activities, and the value of standard deviation was also not too high or low. Furthermore, Skewness and Kurtosis values for all the variables were also within an acceptable range. Thus, the results did not present any data normality issues. Pearson correlation analysis indicated a modest correlation among the variables, and the correlation coefficients were in the presumed directions. For instance, there was a statistically significant positive correlation found between perceived CSR and organizational identification $(0.47, p<0.01)$. Further, a statistically significant negative correlation of organizational identification with turnover intention $(-0.35, p<0.05)$ and organizational deviance $(-0.11, p<0.05)$ was also found. There was also a statistically significant positive correlation of abusive supervision with employees' organizational deviance $0.37, p<0.05$ ) and turnover intention $(0.51, p<0.05)$.

Table 3. Descriptive Statistics and Correlation of Variables.

\begin{tabular}{|c|c|c|c|c|c|c|c|c|}
\hline & Mean & SD & Skewness & Kurtosis & 1 & 2 & 3 & 4 \\
\hline \multicolumn{9}{|l|}{ Level 1 (Individual) } \\
\hline 1. Perceived CSR & 3.79 & 0.78 & -1.02 & 0.70 & 1 & & & \\
\hline 2. OID & 3.03 & 0.85 & -0.85 & 0.09 & $0.47^{* *}$ & 1 & & \\
\hline 3. Turnover Intention & 3.02 & 1.09 & 0.65 & -0.34 & $-0.23 * *$ & 0.35 * & 1 & \\
\hline 4. Organizational Deviance & 2.95 & 1.15 & 1.07 & 0.70 & $-0.31 *$ & $-0.11 *$ & 0.15 & 1 \\
\hline \multicolumn{9}{|l|}{ Level 2 (Group) } \\
\hline 5. Abusive Supervision & 2.97 & 0.43 & 1.15 & 0.66 & -0.17 & $-0.22 * *$ & $0.51 * *$ & $0.37^{* *}$ \\
\hline
\end{tabular}

\subsection{Measurement Model}

Single level confirmatory factor analyses results indicated good model fit values of $\chi 2 / \mathrm{d} f=1.133$, RMSEA $=0.020$, SRMR $=0.011, C F I=0.925$, and TLI $=0.911$. MCFA model fit indices were $\chi 2 / \mathrm{d} f=2.11$, RMSEA $=0.06, \mathrm{SRMR}=0.04, \mathrm{CFI}=0.94$, and TLI $=0.92$. Furthermore, all the scales were tested for convergent and discriminant validity and reliability as well.

\subsection{Hypothesis Testing}

Structural equation modeling techniques were utilized to test direct and indirect effects. The structural model results for individual-level direct effects are presented in Table 4 . Fit Indices for this model were CMIN/DF $=1.14, \mathrm{RMSEA}=0.04, \mathrm{SRMR}=0.011, \mathrm{CFI}=0.940$ and $\mathrm{TLI}=0.931$. The regression coefficient for perceived CSR and organizational identification was $0.43, p<0.01$, which shows that the perceived CSR has a statistically significant positive impact on organizational identification. By keeping all other things constant, if perceived CSR increases by one percent, then organizational identification increases by $43 \%$. Further, organizational identification was affecting 
employees' turnover intention and organizational deviance negatively and significantly $(-0.09, p<0.05$, and $-0.23 p<0.05)$, respectively.

Table 4. Summary of Individual-Level Direct Effects.

\begin{tabular}{lcc}
\hline & Estimate & $p$-value \\
\hline Perceived CSR $\rightarrow$ Identification & $0.43^{*}$ & $<0.01$ \\
Identification $\rightarrow$ Turnover Intention & $-0.09^{* *}$ & 0.043 \\
Identification $\rightarrow$ Organizational Deviance & $-0.23^{* *}$ & 0.021 \\
Perceived CSR $\rightarrow$ Turnover Intention & $-0.03^{* *}$ & 0.048 \\
Perceived CSR $\rightarrow$ Organizational Deviance & $-0.05^{* *}$ & 0.041 \\
\hline
\end{tabular}

Notes: ${ }^{*} p<0.05,{ }^{* *} p<0.01$, Identification $=$ Organizational Identification.

This research hypothesizes that organization identification mediates the effect of perceived CSR on turnover intention (H1a) and organizational deviance $(\mathrm{H} 1 \mathrm{~b})$. The results are reported in Table 5 . It was found that perceived CSR was positively and significantly associated with organizational identification, and organizational identification is significantly and negatively linked with turnover intention and organizational deviance. These results indicated the mediation of organizational identification. However, we directly investigated the mediation model with a bootstrap and at a CI of $95 \%$.

Table 5. Summary of Indirect Effects.

\begin{tabular}{cccc}
\hline & Estimates & $\mathbf{9 5 \%}$ CI & Remarks \\
\hline Perceived CSR $\rightarrow$ OID $\rightarrow$ TI & $-0.04^{* *}$ & {$[-0.06,-0.02]$} & Supported (H1a) \\
Perceived CSR $\rightarrow$ OID $\rightarrow$ OD & $-0.10^{*}$ & {$[-0.14,-0.06]$} & Supported (H1b) \\
Perceived CSR $x$ AS $\rightarrow$ OID $\rightarrow$ TI & -0.02 & {$[-0.09,0.07]$} & Not supported (H2a) \\
Perceived CSR $x$ AS $\rightarrow$ OID $\rightarrow$ OD. & $-0.07^{* *}$ & {$[-0.13,-0.02]$} & Supported (H2b)
\end{tabular}

Notes: [Total effect of Perceived CSR $\rightarrow \mathrm{TI}=-0.07^{* *}$; Mediation of OID: 0.04/0.07 $=57 \%$ ], [Total effect of Perceived $\mathrm{CSR} \rightarrow \mathrm{OD}=-0.15 *$; Mediation of OID: $0.10 / 0.15=66 \%]^{*} p<0.05, * * p<0.01, \mathrm{CI}=$ Confidence Interval, $\mathrm{AS}=$ Abusive Supervision, OID = Organizational Identification, TI = Turnover Intention, OD = Organizational Deviance. $* p<0.05,{ }^{* *} p<0.01$.

We found that the indirect effect of perceived CSR through the mediation of organizational identification on turnover intention was -0.04 (95\% CI [-0.06, -0.02]), and for organizational deviance, it was $-0.10(95 \% \mathrm{CI}[-0.14,-0.06])$. All the confidence intervals do not include zero. Therefore, both $\mathrm{H}_{1 \mathrm{a}}$ and $\mathrm{H}_{1 \mathrm{~b}}$ were supported. In Hypothesis 2, we proposed that abusive supervision would moderate the relationship of perceived CSR with turnover intention and organizational deviance through the mediation of organizational identification. To test the contingency of abusive supervision on the indirect effect, first of all, we examined the interaction of perceived CSR and abusive supervision, and found that this interaction term is significantly related to organizational identification $(0.23, p<0.05)$, which also significantly affects turnover intention $(-0.09, p<0.05)$ and organization deviance $(-0.23 p<0.05)$. Furthermore, the moderated mediation model was directly tested as well with a bootstrap at a $95 \%$ CI. The moderated mediation results are presented in Table 5, which shows that the values for turnover intention were $-0.02(95 \% \mathrm{CI}[-0.09,0.07])$ and the values for organizational deviance were $-0.07(95 \%$ CI $[-0.13,-0.02])$. The confidence intervals included zero for turnover intention, while confidence intervals for organizational deviance did not include zero. Hence, our results did not support H2a, whereas $\mathrm{H} 2 \mathrm{~b}$ was supported. To understand the moderation of abusive supervision on CSR perception and organizational identification, we plotted the moderation results in Figure 2. They showed that the relationship between perceived CSR and organizational identification is stronger when abusive supervision is low, whereas this relationship is weaker with a high level of abusive supervision. 


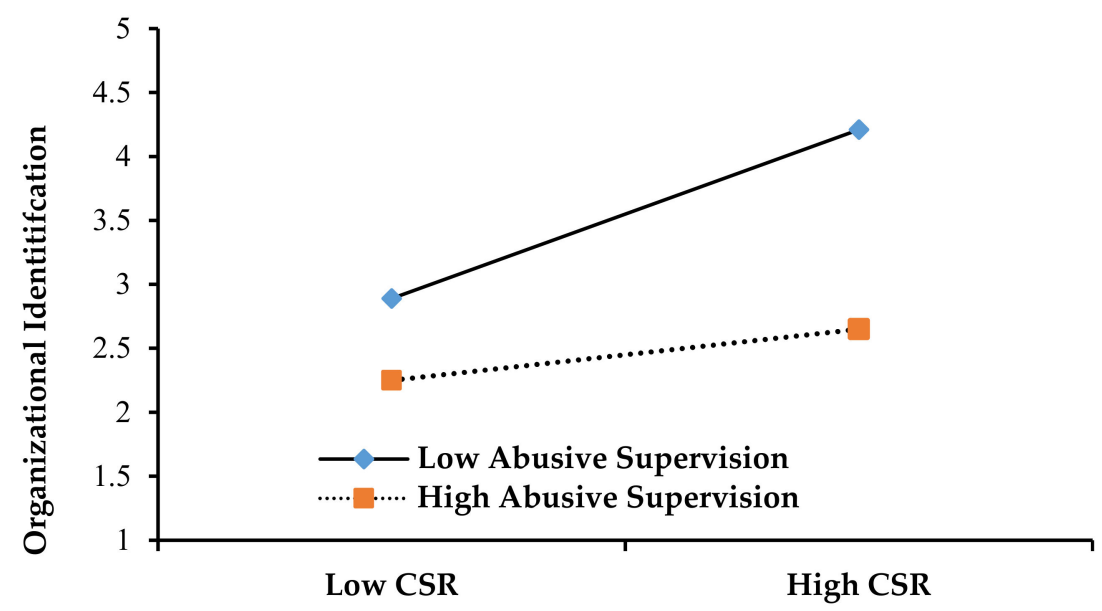

Figure 2. Moderation of abusive supervision.

Moreover, we hypothesized that group-level abusive supervision is positively related to turnover intention (H3a) and organizational deviance (H3b). We found a statistically significant positive effect of group-level abusive supervision on individual-level organizational deviance $(0.19, p<0.05)$. However, we found a statistically insignificant positive impact of abusive supervision on employee turnover intention $(0.06, p<0.072)$. The results are presented in Table 6 . Thus, H3a was not supported as the results remained statistically insignificant, but $\mathrm{H} 3 \mathrm{~b}$ was supported. With the ceteris paribus effect, with a one percent increase in abusive supervision, employees' organizational deviance increases by $19 \%$.

Table 6. Summary of Cross-Level Direct Effects.

\begin{tabular}{cccc}
\hline & Estimate & $p$-Value & Remarks \\
\hline Abusive supervision $\rightarrow$ TI & 0.06 & 0.072 & not supported $\left(\mathrm{H}_{3 \mathrm{a}}\right)$ \\
Abusive supervision $\rightarrow$ OD & $0.19^{* *}$ & 0.029 & supported $\left(\mathrm{H}_{3 \mathrm{~b}}\right)$ \\
Perceived CSR $x$ AS $\rightarrow$ OID & $0.23^{* *}$ & 0.03 & \\
\hline
\end{tabular}

Notes: AS = Abusive Supervision, OID = Organizational Identification, TI = Turnover Intention, OD = Organizational Deviance, ${ }^{* *} p<0.01$.

Figure 3 summarizes all the direct and indirect results presented in the aforementioned tables. In the figure, PCSR is the perception of CSR and PCSR ${ }^{*}$ Abusive supervision is the interaction term that explains the cross-level moderation of abusive supervision on the indirect effect of employees' perceived CSR on their turnover intention and organizational deviance through the mediation of organizational identification.

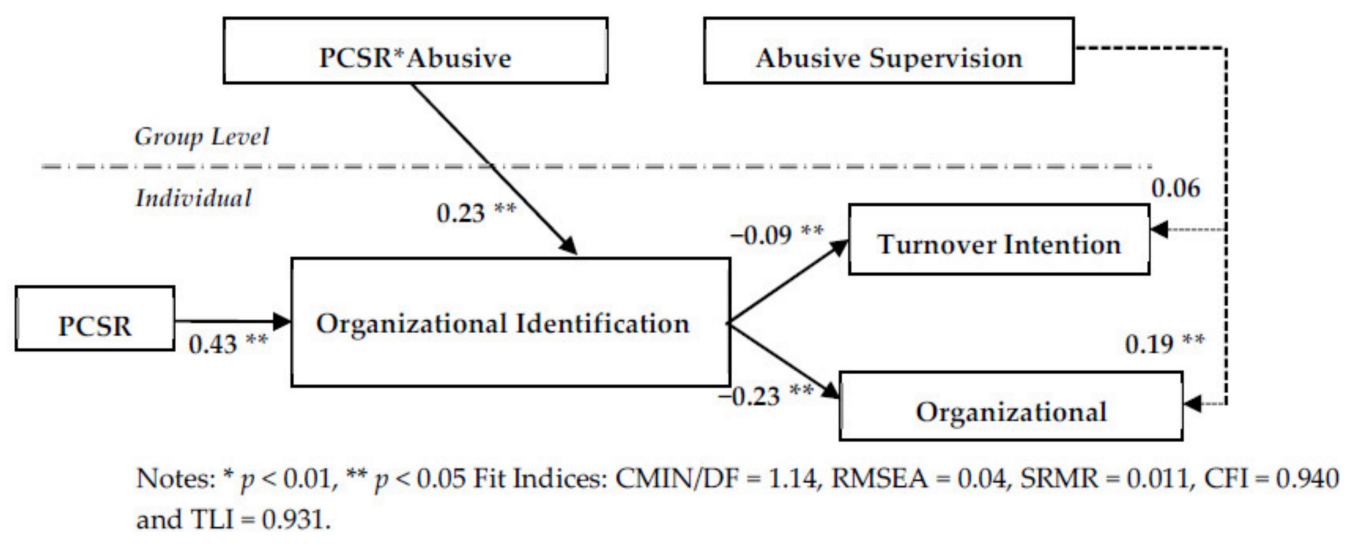

Figure 3. Path analysis results. 


\section{Discussions and Conclusion}

This research empirically examines an essential framework to contribute to the ongoing debate on perceived CSR and employees' workplace behaviors. Primarily, the purpose of this research is to investigate the indirect effect of employees' CSR perceptions on their turnover intention and organizational identification with the mediation of organizational identification. Moreover, this study also seeks insights into this relationship by considering the cross-level boundary condition of an abusive supervisor. Several previous studies had also been conducted to analyze similar relationships to the ones considered in this research. However, this study offers numerous new insights and proves its originality by being one of the first attempts to examine the indirect effect of perceived CSR on two negative behaviors: turnover intention and organizational deviance, with the mediation of organizational identification and multilevel boundary condition of abusive supervision. So far, most of the existing research has focused on those mechanism and boundary conditions which strengthen this relationship [11]. However, this study indicates that it is also essential to concentrate on factors or contingencies that can be adversely affected by abusive supervision. Further, this research also addresses a recent call for multilevel research.

We found a statistically significant and positive effect of perceived CSR on organizational identification and that further organizational identification is significantly and negatively related to turnover intention and organizational identification. Our results are consistent with existing literature [7,60-62]. Thus, it can be explained that when employees positively perceive the CSR of their companies, they then strongly identify with their organization and their perception of oneness is enhanced, which in turn translates into minimizing employees' undesired workplace behavior. Hence, our results are aligned with the social identity theory. However, we found that this relationship becomes ineffective under the boundary condition of abusive supervision, as when abusive supervision is high, then employees' perception of being aligned with the organization is decreased compared to when abusive supervision is low.

\subsection{Implications}

This research progresses our current understanding of employees' CSR perceptions and their workplace behaviors in many ways. For instance, it uses the mediation mechanism of organizational identification to explain the perceived CSR and employee outcomes. The contingency of abusive supervision and its impacts are also examined. There have been several previous attempts to explain CSR perceptions and employees' workplace behaviors using the mediation of organizational identification and contingencies to strengthen this relationship. Yet little attention was previously given to the processes which can explain the effect of CSR perceptions on minimizing undesired workplace employees' behaviors, or to the boundary conditions that can weaken these relationships. Accordingly, our research contributes to the social identity theory by analyzing the effects of perceived CSR on employees on intentions and workplace deviant behavior through the mediation of organizational identification. Thus, we show that when employees positively perceive their organization's CSR initiatives, they tend to strongly identify with their organization, which enhances their perception of oneness and ultimately reduces their intention to leave or engage in deviant behaviors. However, the contingency of abusive supervision weakened this relationship. This research also addresses the recent call in micro-CSR literature by conducting a multilevel investigation.

As far as practical implications are concerned, organizations can concentrate on the model presented in this research and accordingly pursue CSR initiatives. Such understandings of employees' positive perceptions of CSR are essential to minimize undesired workplace behaviors and thus organizations' should not only focus to engaging in CSR initiatives but also on promoting their CSR initiatives to employees. Further, we found that the boundary condition of abusive supervision suppresses the indirect effect of CSR perceptions on turnover intention and workplace deviance. This, it can undermine the employee-organization relationship. Further, abusive supervision can undercut CSR initiatives towards employees' as well as makes employees less likely to believe that their organization 
will treat them fairly or give them care and respect. Thus, it is recommended that organizations focus on their leaders' work-related ethics, organize ethical training, and incorporate ethical training in human development strategies. Third, organizations must give special concentration to internal CSR initiatives because employees are their most indispensable internal stakeholders. Employees are the main group that obtain benefits from internal CSR activities, and they become attached to their organization and show positive workplace behaviors as a result of internal positive CSR activities.

\subsection{Limitations and Future Directions}

This research is not free of limitations that can be considered in further studies. This research was limited to consideration of CSR perceptions, meaning it would be valuable to consider CSR disclosures as well to further examine the model presented in this research. Future research may also incorporate firms-level boundary conditions to explain this micro-level relationship such as CEO traits and characteristics. Several studies on micro-CSR have relied on social identity theory, though may also be useful to use other theoretical perspectives, such as social influence theory [63]. Last but not least, this research was conducted in Pakistan alone. Future research can be conducted by collecting data from multiple countries to uncover cultural and religious factors across different countries to provide a better understanding of CSR perceptions and employee attitudes, behaviors, and resultant relationships.

Author Contributions: Conceptualization, methodology, original draft preparation F.M. and M.S.; software, J.A.; formal analysis, Z.A.; writing, A.H., I.H. and M.; writing-review and editing, F.Q. All authors have read and agreed to the published version of the manuscript.

Funding: This research received no external funding.

Acknowledgments: The authors wish to thank Albert John, and the anonymous reviewers for very helpful suggestions.

Conflicts of Interest: The authors declare no conflict of interest.

\section{Appendix A}

Table A1. Measures.

\begin{tabular}{|c|c|}
\hline \multicolumn{2}{|c|}{ CSR by Maignan and Ferrell [44] 29 items scale } \\
\hline $\begin{array}{l}\text { Our business has a procedure in place to respond to every } \\
\text { customer complaint. }\end{array}$ & Members of our organization follow professional standards. \\
\hline We continually improve the quality of our products. & $\begin{array}{l}\text { Top managers monitor the potential negative impacts of our } \\
\text { activities on our community. }\end{array}$ \\
\hline $\begin{array}{l}\text { We use customer satisfaction as an indicator of our business } \\
\text { performance. }\end{array}$ & We are recognized as a trustworthy company. \\
\hline We have been successful at maximizing our profits. & $\begin{array}{l}\text { Fairness toward co-workers and business partners is an integral part } \\
\text { of our employee evaluation process. }\end{array}$ \\
\hline We strive to lower our operating costs. & $\begin{array}{l}\text { A confidential procedure is in place for employees to report any } \\
\text { misconduct at work (such as stealing or sexual harassment). }\end{array}$ \\
\hline We closely monitor employees' productivity. & $\begin{array}{l}\text { Our salespersons and employees are required to provide full and } \\
\text { accurate information to all customers. }\end{array}$ \\
\hline Top management establishes long-term strategies for our business. & $\begin{array}{l}\text { The salaries offered by our company are higher than industry } \\
\text { averages. }\end{array}$ \\
\hline Managers are informed about relevant environmental laws. & Our business supports employees who acquire additional education. \\
\hline All our products meet legal standards. & $\begin{array}{l}\text { Our business encourages employees to join civic organizations that } \\
\text { support our community. }\end{array}$ \\
\hline Our contractual obligations are always honored. & $\begin{array}{l}\text { Flexible company policies enable employees to better coordinate } \\
\text { work and personal life. }\end{array}$ \\
\hline The managers of this organization try to comply with the law. & Our business gives adequate contributions to charities. \\
\hline $\begin{array}{l}\text { Our company seeks to comply with all laws regulating hiring and } \\
\text { employee benefits. }\end{array}$ & $\begin{array}{l}\text { A program is in place to reduce the amount of energy and materials } \\
\text { wasted in our business. }\end{array}$ \\
\hline $\begin{array}{l}\text { We have programs that encourage the diversity of our workforce } \\
\text { (in terms of age, gender, or race). }\end{array}$ & We encourage partnerships with local businesses and schools. \\
\hline $\begin{array}{l}\text { Internal policies prevent discrimination in employees' } \\
\text { compensation and promotion. }\end{array}$ & Our business supports local sports and cultural activities. \\
\hline Our business has a comprehensive code of conduct. & \\
\hline
\end{tabular}


Table A1. Cont.

\begin{tabular}{|c|c|}
\hline \multicolumn{2}{|c|}{ Organizational identification by Mael and Ashforth [45] 6 items scale } \\
\hline $\begin{array}{l}\text { When someone criticizes my organization it feels like a personal } \\
\text { insult. }\end{array}$ & This organization's successes are my successes. \\
\hline I am very interested in what others think about my organization. & $\begin{array}{l}\text { When someone praises my organization, it feels like a personal } \\
\text { compliment. }\end{array}$ \\
\hline $\begin{array}{l}\text { When I talk about this organization, I usually say we rather than } \\
\text { they. }\end{array}$ & If a story in the media my organization, I would feel embarrassed. \\
\hline \multicolumn{2}{|c|}{ Turnover Intention by Wayne et al. [46] 6 items scale } \\
\hline $\begin{array}{l}\text { As soon as I can find a better job I will leave my company. } \\
\text { I am actively looking for a job outside of my company. } \\
\text { I am seriously thinking of quitting job. }\end{array}$ & $\begin{array}{l}\text { I often think of quitting my job from my company. } \\
\text { I think I will still be working at my company five years from now. }\end{array}$ \\
\hline \multicolumn{2}{|c|}{ Organizational deviance by Bennett and Robinson [30] 12 items scale } \\
\hline Taken property from work without permission & Spent too much time fantasizing or daydreaming instead of working \\
\hline $\begin{array}{l}\text { Falsified a receipt to get reimbursed for more money than you } \\
\text { spent on business expenses }\end{array}$ & $\begin{array}{l}\text { Taken an additional or longer break than is acceptable at your } \\
\text { workplace }\end{array}$ \\
\hline Come in late to work without permission & Littered your work environment \\
\hline Neglected to follow your boss's instructions & Intentionally worked slower than you could have worked \\
\hline $\begin{array}{l}\text { Discussed confidential company information with an } \\
\text { unauthorized person }\end{array}$ & Used an illegal drug or consumed alcohol on the job \\
\hline Put little effort into your work & Dragged out work in order to get overtime \\
\hline \multicolumn{2}{|c|}{ Abusive supervision by Tepper [48] 15 items scale } \\
\hline Ridicules me & Tells me my thoughts or feelings are stupid \\
\hline Gives me the silent treatment & Puts me down in front of others \\
\hline Invades my privacy & Reminds me of my past mistakes and failures \\
\hline Doesn't give me credit for jobs requiring a lot of effort & Blames me to save himself/herself embarrassment \\
\hline Breaks promises he/she makes & Makes negative comments about me to others \\
\hline Expresses anger at me when he/she is mad for another reason & Does not allow me to interact with my coworkers \\
\hline Is rude to me & Lies to me \\
\hline Tells me I'm incompetent & \\
\hline
\end{tabular}

\section{References}

1. Newman, A.; Miao, Q.; Hofman, P.S.; Zhu, C.J. The impact of socially responsible human resource management on employees' organizational citizenship behaviour: The mediating role of organizational identification. Int. J. Hum. Resour. Manag. 2016, 27, 440-455. [CrossRef]

2. Asrar-ul-Haq, M.; Kuchinke, K.P.; Iqbal, A.J. The relationship between corporate social responsibility, job satisfaction, and organizational commitment: Case of Pakistani higher education. J. Clean. Prod. 2017, 142, 2352-2363. [CrossRef]

3. Van Dick, R.; Crawshaw, J.R.; Karpf, S.; Schuh, S.C.; Zhang, X.A. Identity, importance, and their roles in how corporate social responsibility affects workplace attitudes and behavior. J. Bus. Psychol. 2019. [CrossRef]

4. Staniškienè, E.; Stankevičiūtè, Z. Social sustainability measurement framework: The case of employee perspective in a CSR-committed organisation. J. Clean. Prod. 2018, 188, 708-719. [CrossRef]

5. John, A.; Qadeer, F.; Shahzadi, G.; Jia, F. Getting paid to be good: How and when employees respond to corporate social responsibility? J. Clean. Prod. 2019, 215, 784-795. [CrossRef]

6. Grewatsch, S.; Kleindienst, I. When does it pay to be good? Moderators and mediators in the corporate sustainability-Corporate financial performance relationship: A critical review. J. Bus. Ethics 2017, 145, 383-416.

7. Jones, D.A.; Newman, A.; Shao, R.; Cooke, F.L. Advances in employee-focused micro-level research on corporate social responsibility: Situating new contributions within the current state of the literature. J. Bus. Ethics 2019, 157, 293-302. [CrossRef]

8. Rupp, D.E.; Shao, R.; Thornton, M.A.; Skarlicki, D.P. Applicants' and employees' reactions to corporate social responsibility: The moderating effects of first-party justice perceptions and moral identity. Pers. Psychol. 2013, 66, 895-933. [CrossRef]

9. Hameed, I.; Riaz, Z.; Arain, G.A.; Farooq, O. How do internal and external CSR affect employees' organizational identification? A perspective from the group engagement model. Front. Psychol. 2016, 7, 788. [CrossRef] [PubMed]

10. Morgeson, F.P.; Aguinis, H.; Waldman, D.A.; Siegel, D.S. Extending corporate social responsibility research to the human resource management and organizational behavior domains: A look to the future. Pers. Psychol. 2013, 66, 805-824. [CrossRef] 
11. Wang, W.; Fu, Y.; Qiu, H.; Moore, J.H.; Wang, Z. Corporate social responsibility and employee outcomes: A moderated mediation model of organizational identification and moral identity. Front. Psychol. 2017, 8 , 1906. [CrossRef] [PubMed]

12. Glavas, A.; Piderit, S. How does doing good matter. J. Corp. Citizsh. 2009, 36, 51-70. [CrossRef]

13. Ashforth, B.E.; Mael, F. Social identity theory and the organization. Acad. Manag. 1989, 14, $20-39$.

14. Dutton, J.E.; Dukerich, J.M.; Harquail, C.V. Organizational images and member identification. Adm. Sci. Q. 1994, 1994, 239-263. [CrossRef]

15. Ellemers, N.; Kortekaas, P.; Ouwerkerk, J.W. Self-categorisation, commitment to the group and group self-esteem as related but distinct aspects of social identity. Eur. J. Soc. Psychol. 1999, 29, 371-389. [CrossRef]

16. Zappalà, S.; Toscano, F.; Licciardello, S. Towards sustainable organizations: Supervisor support, commitment to change and the mediating role of organizational identification. Sustainability 2019, 11, 805. [CrossRef]

17. Marique, G.; Stinglhamber, F.; Desmette, D.; Caesens, G.; De Zanet, F. The relationship between perceived organizational support and affective commitment: A social identity perspective. Group Organ. Manag. 2013, 38, 68-100. [CrossRef]

18. Aguinis, H. Organizational responsibility: Doing good and doing well. APA Handb. Ind. Organ. Psychol. 2011, 3, 855-879.

19. De Roeck, K.; El Akremi, A.; Swaen, V. Consistency matters! How and when does corporate social responsibility affect employees' organizational identification? J. Manag. Stud. 2016, 53, 1141-1168. [CrossRef]

20. Erdogan, B.; Bauer, T.N.; Taylor, S. Management commitment to the ecological environment and employees: Implications for employee attitudes and citizenship behaviors. Hum. Relat. 2015, 68, 1669-1691. [CrossRef]

21. Zulfiqar, S.; Sadaf, R.; Popp, J.; Vveinhardt, J.; Máté, D. An examination of corporate social responsibility and employee behavior: The case of Pakistan. Sustainability 2019, 11, 3515. [CrossRef]

22. Shen, J.; Benson, J. When CSR is a social norm: How socially responsible human resource management affects employee work behavior. J. Manag. 2016, 42, 1723-1746. [CrossRef]

23. Carmeli, A.; Gilat, G.; Waldman, D. The role of perceived organizational performance in organizational identification, adjustment and job performance. J. Manag. Stud. 2007, 44, 972-992. [CrossRef]

24. Abdullah, M.I.; Ashraf, S.; Sarfraz, M.J.S. The organizational identification perspective of CSR on creative performance: The moderating role of creative self-efficacy. Sustainability 2017, 9, 2125. [CrossRef]

25. Cheema, S.; Afsar, B.; Al-Ghazali, B.M.; Maqsoom, A. How employee's perceived corporate social responsibility affects employee's pro-environmental behaviour? The influence of organizational identification, corporate entrepreneurship, and environmental consciousness. Corp. Soc. Responsib. Environ. Manag. 2019, 27, 616-629. [CrossRef]

26. El Akremi, A.; Gond, J.P.; Swaen, V.; De Roeck, K.; Igalens, J. How do employees perceive corporate responsibility? Development and validation of a multidimensional corporate stakeholder responsibility scale. J. Manag. 2018, 44, 619-657.

27. Macy, B.A.; Mirvis, P. Assessing rates and costs of individual work behaviors. In Assessing Organizational Change; Seashore, S.E., Lawler, E.E., Mirvis, P.H., Eds.; Wiley: New York, NY, USA, 1983; pp. 139-177.

28. Du, S.; Bhattacharya, C.; Sen, S. Corporate social responsibility, multi-faceted job-products, and employee outcomes. J. Bus. Ethics 2015, 131, 319-335. [CrossRef]

29. Cole, M.S.; Bruch, H. Organizational identity strength, identification, and commitment and their relationships to turnover intention: Does organizational hierarchy matter? J. Organ. Behav. 2006, 27, 585-605. [CrossRef]

30. Bennett, R.J.; Robinson, S. Development of a measure of workplace deviance. J. Appl. Psychol. 2000, 85, 349. [CrossRef]

31. Javed, B.; Fatima, T.; Yasin, R.M.; Jahanzeb, S.; Rawwas, M.Y. Impact of abusive supervision on deviant work behavior: The role of Islamic work ethic. Bus. Ethics: Eur. Rev. 2019, 28, 221-233. [CrossRef]

32. Kotler, P.; Lee, N. Best of breed: When it comes to gaining a market edge while supporting a social cause,"corporate social marketing" leads the pack. Soc. Mark. Q. 2005, 11, 91-103. [CrossRef]

33. Tepper, B. Abusive supervision in work organizations: Review, synthesis, and research agenda. J. Manag. 2007, 33, 261-289. [CrossRef]

34. Aquino, K.; Tripp, T.M.; Bies, R. Getting even or moving on? Power, procedural justice, and types of offense as predictors of revenge, forgiveness, reconciliation, and avoidance in organizations. J. Appl. Psychol. 2006, 91, 653. [CrossRef] [PubMed] 
35. Zellars, K.L.; Tepper, B.J.; Duffy, M. Abusive supervision and subordinates' organizational citizenship behavior. J. Appl. Psychol. 2002, 87, 1068. [CrossRef]

36. Klaussner, S. Engulfed in the abyss: The emergence of abusive supervision as an escalating process of supervisor-subordinate interaction. Hum. Relat. 2014, 67, 311-332. [CrossRef]

37. Hershcovis, M.S.; Reich, T.C.; Parker, S.K.; Bozeman, J. The relationship between workplace aggression and target deviant behaviour: The moderating roles of power and task interdependence. Work Stress 2012, 26, 1-20. [CrossRef]

38. Fox, S.; Spector, P.E.; Miles, D.J. Counterproductive work behavior (CWB) in response to job stressors and organizational justice: Some mediator and moderator tests for autonomy and emotions. J. Vocat. Behav. 2001, 59, 291-309. [CrossRef]

39. Harris, K.J.; Kacmar, K.M.; Zivnuska, S.J. An investigation of abusive supervision as a predictor of performance and the meaning of work as a moderator of the relationshi. Lead. Q. 2007, 18, 252-263. [CrossRef]

40. Blau, P. Power and Exchange in Social Life; Wiley \& Sons: New York, NY, USA, 1964.

41. Ren, C.R.; Guo, C. Middle managers' strategic role in the corporate entrepreneurial process: Attention-based effects. J. Manag. 2011, 37, 1586-1610. [CrossRef]

42. Shahzadi, G.; Qadeer, F.; John, A.; Jia, J.F. CSR and identification: The contingencies of employees' personal traits and desire. Soc. Responsib. J. 2019. [CrossRef]

43. Podsakoff, P.M. Common method biases in behavioral research: A critical review of the literature and recommended remedies. J. Appl. Psychol. 2003, 88, 879. [CrossRef] [PubMed]

44. Maignan, I.; Ferrell, O. Antecedents and benefits of corporate citizenship: An investigation of French businesses. J. Bus. Res. 2001, 51, 37-51. [CrossRef]

45. Mael, F.; Ashforth, B. Alumni and their alma mater: A partial test of the reformulated model of organizational identification. J. Organ. Behav. 1992, 13, 103-123. [CrossRef]

46. Wayne, S.J.; Shore, L.M.; Liden, R. Perceived organizational support and leader-member exchange: A social exchange perspective. Acad. Manag. J. 1997, 40, 82-111.

47. Henle, C.A.; Giacalone, R.A.; Jurkiewicz, C.L. The role of ethical ideology in workplace deviance. J. Bus. Ethics. 2005, 56, 219-230. [CrossRef]

48. Tepper, B.J. Consequences of abusive supervision. Acad. Manag. J. 2000, 43, 178-190.

49. Riketta, M.J. Organizational identification: A meta-analysis. J. Vocat. Behav. 2005, 66, 358-384. [CrossRef]

50. Muthén, L.K.; Muthén, B.O. Mplus User's Guide, 6th ed.; Muthen \& Muthen: Los Angeles, CA, USA, 2010.

51. Hair, J.F.; Black, W.C.; Babin, B.J.; Anderson, R.E.; Tatham, R.L. Multivariate Data Analysis; Prentice hall: Upper Saddle River, NJ, USA, 1998.

52. Chan, D. Functional relations among constructs in the same content domain at different levels of analysis: A typology of composition models. J. Appl. Psychol. 1998, 83, 234. [CrossRef]

53. Farh, C.I.; Chen, Z. Beyond the individual victim: Multilevel consequences of abusive supervision in teams. J. Appl. Psychol. 2014, 9, 1074. [CrossRef]

54. Muthén, B.O. Multilevel covariance structure analysis. Sociol. Methods Res. 1994, 22, 376-398. [CrossRef]

55. Preacher, K.J.; Zhang, Z.; Zyphur, M.J. Alternative methods for assessing mediation in multilevel data: The advantages of multilevel SEM. Struct. Equ. Modeling 2011, 18, 161-182. [CrossRef]

56. James, L.R. Aggregation bias in estimates of perceptual agreement. J. Appl. Psychol. 1982, 67, 219. [CrossRef]

57. James, L.R.; Demaree, R.G.; Wolf, G. Rwg: An assessment of within-group interrater agreement. J. Appl. Psychol. 1993, 78, 306. [CrossRef]

58. Kim, A.; Kim, Y.; Han, K.; Jackson, S.E.; Ployhart, R.E. Multilevel influences on voluntary workplace green behavior: Individual differences, leader behavior, and coworker advocacy. J. Manag. 2017, 43, 1335-1358. [CrossRef]

59. Tabachnick, B.G.; Fidell, L.S.; Ullman, J.B. Using Multivariate Statistics; Pearson: Boston, MA, USA, 2007.

60. Akbaş, H.E. Analyzing the Effect of Corporate Social Responsibility Perception on Organizational Identification from Employee Perspective. In Ethics, Social Responsibility and Sustainability in Marketing; Springer: Berlin/Heidelberg, Germany, 2019; pp. 65-81.

61. Brammer, S.; He, H.; Mellahi, K. Corporate social responsibility, employee organizational identification, and creative effort: The moderating impact of corporate ability. Group Organ. Manag. 2015, 40, 323-352. [CrossRef] 
62. Glavas, A. Corporate social responsibility and organizational psychology: An integrative review. Front. Psychol. 2016, 7, 144. [CrossRef]

63. John, A.; Qadeer, F.; Shahzadi, G.; Jia, F. Corporate social responsibility and employee's desire: A social influence perspective. Serv. Ind. J. 2017, 37, 819-832. [CrossRef] 